\title{
Aikuiskasvatustiede ja tutkimus tänään - huomenna
}

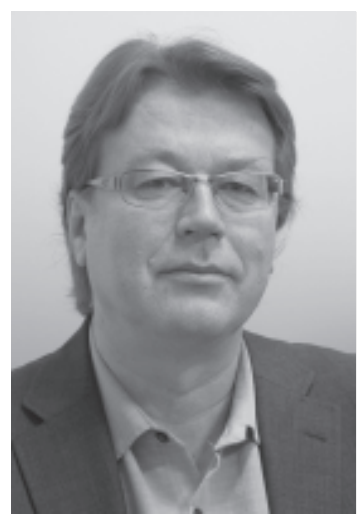

\begin{abstract}
$\mathrm{A}_{\mathrm{i}}$
kuiskasvatuksen tutkijatapaamisessa helmikuussa Joensuussa kysyttiin (ja vastattiin), mitä iloa on tutkimuksesta. Millaisin tarkoituksin aikuiskoulutustutkimusta tehdään ja mihin tarpeisiin sillä vastataan? Millaista aikuiskasvatustutkimusta tarvitaan, ja kuka tarvitsee? Onko aikuiskasvatuksella tieteenä jokin oma intressi? Jos on, onko Suomessa harjoitettava aikuiskoulutuksen ja -kasvatuksen tutkimus sen mukaista?
\end{abstract}

Tieteellinen tutkimus on lähtökohtaisesti kriittistä. Kriittisyys kuuluu tieteellisen toiminnan luonteeseen, vaikkakin se saattaa toimeentulonsa jatkuvuudesta huolestuneen projektitutkijan nopeatempoisessa elämässä unohtua. Ihmistieteissä kriittisyys tarkoittaa ennen kaikkea sitä, että tutkimus ei ota olemassa olevia oloja annettuina. Yhteiskunnallinen todellisuus muotoutuu ihmisten valintojen ja toiminnan seurauksena, vaikkakaan ei koskaan sellaiseksi kuin tavoitellaan. Tulevaisuuskaan ei ole vaihtoehdoton, vaikka valtaa pitävät niin vakuuttamalla yrittävät toimintaansa legitimoida.

$\mathrm{T}$ ässä numerossa alkaa kirjoitussarja aikuiskasvatustieteen ja -tutkimuksen tilasta ja kehittämistarpeista. Keskustelun avaavat kannanotoillaan emeritusprofessori Ari Antikainen Joensuun yliopistosta ja tutkija Kristiina Brunila Helsingin yliopistosta.

Suomessa on aikuiskasvatuksen professuureja seitsemässä yliopistossa. Professorikunnan ohessa on lukuisa joukko muita ansioituneita aikuiskasvatuksen ja-koulutuksen tutkijoita paisti kasvatustieteiden myös yhteiskuntatieteiden ja humanististen tieteiden piirissä. Aikuiskoulutuksen kentällä toimivilla opetus- ja hallintohenkilöstön kokemus ja näkemys tutkimuksen tilasta on niin ikään arvokasta. Kutsun lehden lukijat puheenvuoroillaan mukaan alkavaan keskusteluun. Ainakin professorikunnalta rohkenen toivoa aiheesta panosta tiedeartikkeleiden osastolle.

Kriittinen ote aiheen käsittelyssä on tietysti toivottavaa kaikilta Aikuiskasvatuslehteen artikkeleita tarjoavilta. Aikuiskasvatustutkimukselta sopii odottaa analyysejä esimerkiksi siitä, mitä tekemistä - jos mitään - aikuiskoulutuksella on sellaisten yhteiskunnallisesti merkittävien ilmiöiden kuin sosiaalinen ja taloudellinen eriarvoisuus, väestön hallintatapojen muutokset, prekariaatin ja työtätekevien köyhien asema työvoiman käyttötapojen muutoksessa. Työvoiman käyttö on parin viime vuosikymmenen aikana muuttunut siinä määrin, että uran käsitekin on joutunut uudelleen arvioitavaksi, mihin teemaan tämän numeron artikkeleissakin paneudutaan. Katkonaisuus ja epävarmuus ovat muuttumassa normaaliksi. 
Työttömyyden yleistyessä yhä useamman kansalaisen elämänsuunnittelu vaikeutuu. EU-maissa on tätä nykyä yli 23 miljoonaa työtöntä, ja määrä kasvaa. Työttömyys koskettaa pahimmin nuoria, naisia, yli 55-vuotiaita sekä maahanmuuttajia. Alle 25-vuotiaita on työttömänä yli viisi miljoonaa, minkä vuoksi valtava joukko eurooppalaisia nuoria ei saa edes kohtuullisia lähtökohtia työuran rakentamiselle ja elämänsä suunnitteluun. Koulutuksella liikutellaan massoja, mutta väestö kouluttautuu yksilöinä. Koulutusta ja tutkintoja hankkimalla yksilöt varustautuvat kilpailuun työmarkkinoilla. Suomen kaltaisessa kroonisen alityöllisyyden (tai joukkotyöttömyyden) yhteiskunnassa koulutussuorituksilla ja tutkinnoilla käytävä kilpavarustelu tapahtuu jatkuvan putoamisen uhkan alla. Aikuiskoulutusta on perusteltua katsoa myös osana nykyistä hallintavaltaa.

$\mathrm{O}_{\mathrm{p}}$

petusministeriö on ollut tämän vuoden toukokuun alusta lähtien opetus- ja kulttuuriministeriö, okm. Maritan Savolan johtama aikuiskoulutuksen tulosalue on lakkautettu ja sen tehtävät hajautettu kolmeen eri yksikköön koulutus- ja tiedepolitiikan osastolla. Vapaasta sivistystyöstä vastaa jatkossa yleissivistävän koulutuksen yksikkö ja ammatillisesta aikuiskoulutuksesta ammatillisen koulutuksen yksikkö. Korkea-asteen aikuiskoulutuksen tehtävät siirretään korkeakoulu- ja tiedeyksikköön. Aikuiskoulutuksen tehtäväalueen ja kehittämisen hajottaminen ei ensisijaisesti pohjaudu asiaperusteisiin. Kun ministeriön henkilöstön määrää vähennetään valtionhallinnon tuottavuusohjelman tavoitteiden mukaisesti, yksin aikuiskoulutukseen keskittyvää henkilöstöä ei jää riittävästi. Tämä on ymmärrettävästi aiheuttanut monilla tahoilla huolta siitä, riittääkö ministeriössä asiantuntemusta aikuiskoulutuksen ja aikuiskoulutuspolitiikan kehittämiseen ja aikuiskoulutuksen erityisluonteen ymmärtämiseen. Ministeriöstä vakuutetaan, että muun koulutuksen yhteyteen uudella tavalla integroiden aikuiskoulutustehtävät hoidetaan entistä paremmin.

Maalailematta ennenaikaisesti piruja seinille, mieleen tulee tarina kettutarhaa ja kanalaa pitävästä pariskunnasta. Emäntä hoiti menestyksellisesti kanat ja isäntä yhtä menestyksellisesti ketut. Emännän yllättäen kuoltua kanankasvatus osoittautui isännälle vaikeaksi ja kettutarhauksen lisäksi työlääksi tehtäväksi. Palkallista työvoimaa ei ollut varaa ottaa, eikä hän halunnut luopua kanoista. Isäntä kurssille. Uusiin talous- ja organisaatio-oppeihin perehdyttyään hän päätyi kokoamaan erilliset yksiköt yhteen suuremmaksi kokonaisuudeksi. Kustannussäästöjä ja synergiaetuja saadakseen hän laittoi ketut ja kanat samaan tarhaan.

\section{Heikki Silvennoinen}

